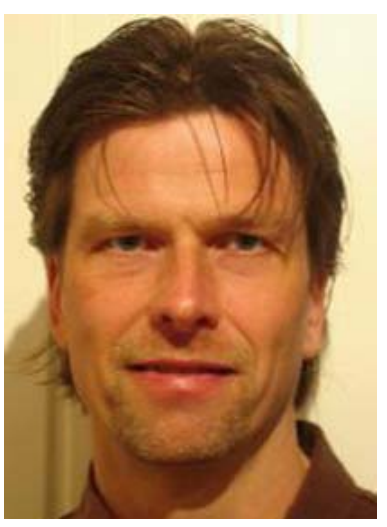

Petri Salo

\section{Sisaret hennot valkoiset?}

I

Ideoidessamme lehden toimituskunnassa puolisen toista vuotta sitten "hoivan, vastuun ja huolenpidon” työnimellä kulkenutta teemanumeroa emme saattaneet mitenkään ennakoida sen ilmestyvän ajankohtana, jolloin kysymys siitä, minkä suuruisen palkan terveyden- ja sairaanhoidon ammattilaiset ovat työstään ansainneet ,on kulminoitumassa hoitajien työtaisteluksi. TEHY:n, terveydenhuolto- ja sosiaalialan koulutetun henkilöstön ammattijärjestön, irtisanoutumisuhka ja sen mahdolliset seuraukset ovat pakottaneet meidät kaikki pohtimaan kokemuksiamme ja niihin perustuvia näkemyksiämme suomalaisesta sairaanhoidosta ja hoitajien työstä: Mitkä ovat hoitotyön lähtökohdat ja edellytykset? Mikä tekee sitä erityisen vaativaa ja arvokasta? Mitä on ammattitaito hoitotyössä? Entä koulutuksen merkitys ammattitaidon ylläpitämisessä? Näihin kysymyksiin löytyy vastauksia useasta tämän teemanumeron artikkelista.

Kysymys hoitajien työstä, sen luonteesta, merkityksestä ja arvostuksesta on mediassa muotoutunut pitkälti kysymykseksi työmarkkinapoliittisen kamppailun oikeutuksesta. Lisäksi se on kiteytynyt palkankorotuksen määrään. Ovatko hoitajien palkkavaatimukset oikeutetut? Entä heidän työtaistelutoimensa? Kenen on vastuu, jos joukkoirtisanoutumiset johtavat ihmishenkien menetyksiin? Makrotason tarkastelu vaikuttaa jälleen kerran olevan syvässä ristiriidassa arkisten mikrotason kokemusten kanssa. Mutta meillä hoivamaallikoilla on mielestäni oikeus muodostaa kantamme omien kokemustemme perusteella. Tässähän liikutaan yhdellä tärkeimmistä arjen politiikan alueista.

Omat kokemukseni vuosien varrelta ovat vain ja ainoastaan positiiviset. En saata muistaa koskaan kohdanneeni hentoja valkoisia sisaria vaan ainoastaan piinkovia, useimmiten valkoisiin pukeutuneita hoitoalan ammattilaisia. He ovat sekä ammattitaidollaan että kyvyllään kohdata potilaansa (toisen ihmisen) vakuuttaneet minut myös niissä akuuteissa tilanteissa, joissa huoli ja epävarmuus ovat olleet vahvasti läsnä. En kuitenkaan uskalla enkä halua yleistää henkilökohtaisia kokemuksiani. Sekä ruumiin että mielenterveyden hoitoon liittyvät kohtaamiset alan ammattilaisten kanssa ovat usein hyvin latautuneita tilanteita, joissa me reagoimme monin eri tavoin.

Hoitotyö on lääketieteelliseen tietoon perustuvaa ihmissuhdetyötä. Muutama ystävällinen sana terveyskeskuksen vuodeosaston iltakierroksella saattaa parantaa yöksi jaettujen lääkkeiden tehoa. Juuri tässä piilee hoitotyön paradoksi. Ihmiskehoa fysiologisesti hoidettaessa hoidon täsmällisyyttä ja tehokkuutta, eli laatua, kyetään osin mittaamaan hyvinkin yksiselitteisen täsmällisesti. Me ihmiset olemme kuitenkin monimutkaisia psykofyysisiä kokonaisuuksia. Hoitotyöhön lähes aina liittyvään toisen ihmisen kohtaamiseen ei kovalla lääketieteellä ole nähdäkseni paljoakaan yksiselitteistä sanottavaa. Siirrytään tunteiden sävyttämälle huolenpidon alueelle, jossa sairauden aiheuttamaa huolta ja eksistentiaalista kriisiä hoidetaan inhimillisyydellä ja empatialla. Hoitajalle tunteet ja huolenpito ovat yhtäaikaisesti ihmisenä olemisen ja ammatillisen 
toiminnan perusedellytys. Työssään taitava hoitaja kykenee hallitsemaan ja säätelemään sekä kehoaan että tunteitaan erilaisten tilanteiden ja potilaiden edellyttämällä tavalla, itseään loppuun polttamatta. Kati Tikkamäen saattohoitajien työtä käsittelevässä artikkelissa tunteiden, erityisesti empatian merkitys saavuttaa lakipisteensä. Mikäli saattohoitaja haluaa selviytyä työssään elävänä, hän ei voi kuolla jokaisen potilaan mukana. Ammattinsa hallitseva saattohoitaja on oppinut suojaamaan itsensä.

Siirryttäessä hoidosta kuntoutukseen ammatillisen kohtaamisen lähtökohdat muuttuvat. Vastuu siirtyy asteittain hoitajalta potilaalle, asiantuntijalta maallikolle. Kyetäkseen kuntoutumaan potilaan on opittava toimimaan aiemmasta poikkeavalla tavalla. Tämän lisäksi hänen olisi usein kyettävä kohtaamaan ja näkemään itsensä toisin. Eksistentiaalinen kriisi muuttaa muotoaan. Samalla kun hoitajan rooli muuttuu enemmän ohjaavaksi, kohtaamisen fyysissosiaalinen viitekehys laajenee, sairaalasta tai hoitolaitoksesta kuntoutujan arkielämän ympäristöön. Jatkumon toisessa päässä inhimillinen vastuu hoivasta ja huolenpidosta on siirtynyt ammattilaiselta amatöörille, hoitajalta lähimmäiselle.

$\mathrm{T}$

ämän teemanumeron artikkeleissa liikutaan monen toisiaan hyvinkin lähellä olevan tieteenalan leikkauskohdissa ja välimaastoissa. Niissä tarkastellaan, Annu Hahon artikkelissaan esittelemien hoitotieteen käsittein, niin ammatillisen kuin luonnollisen hoitamisen edellytyksiä ja käytäntöjä. Aikuiskasvatustieteen edustajana muotoilen saman asian hieman toisin. Hoivaa ja kuntoutusta tarkastellaan elinikäisen oppimisen ja ihmisenä kasvamisen formaaleissa, non-formaaleissa sekä informaaleissa konteksteissa. Näkökulma hoivaan ja huolenpitoon on vahvasti sukupuolittunut. Ainoastaan kuuden vuoden takaisessa "Aikuiskasvatus ja sukupuoli” -teemanumeron kirjoittajissa naisten osuus oli likimain yhtä suuri kuin tässä käsillä olevassa teemanumerossa.

L

opuksi oma henkilökohtainen kantani hoitajien työtaistelutoimiin, jotka ovat lehden ilmestyessä mitä ilmeisimmin jo kulminoituneet. Yhdyn siihen suomalaisten hoivamaallikoiden enemmistöön, joiden mielestä hoitajat ovat vaatimansa palkankorotuksen ehdottomasti ansainneet. Hoitajien ammattijärjestö TEHY on esiintynyt työtaistelun aikana harvinaisen päättäväisenä ja yksimielisenä. Voisiko tämä johtua siitä, että hoitajat ovat työssään tottuneet päivittäin jakamaan voimakkaat tunnekokemukset kollegojensa kanssa, työyhteisön sisällä?

\section{PETRI SALO \\ psalo@abo.fi}

